Ormerod, J. A. (1910). In A System of Medicine, edited by C. Allbutt and H. D. Rolleston, vol. 8. Macmillan, London. Sargant, W. (1951). Lancet, 2, 87.

Stafford-Clark D (1958) Brit med. J., 2.446.

Wall, J. H. (1959). Amer. J. Psychiat., 115, 997.

Williams, E. (1958). Brit. med. J., 2, 190.

\section{CLINICAL EVALUATION OF}

\section{BENZTHIAZIDE, AN ORAL DIURETIC}

BY

\section{W. H. HAVARD, M.A., D.M., M.R.C.P. AND}

PHILIP H. N. WOOD, M.B., B.S.

From the Departments of Medicine and Pathology, St. Bartholomew's Hospital, London

The synthesis of chlorothiazide has stimulated the search for other substitution derivatives of the benzothiadiazine nucleus in the hope that these newer compounds might be less prone to induce potassium depletion. The newest compound belonging to this group is benzthiazide ( 3 - benzylthiomethyl - 6 - chloro - 7 - sulphamyl - 1,2,4 benzothiadiazine-1,1-dioxide) (Fig. 1). The mode of action of chlorothiazide has been studied extensively (Bayliss et al., 1958; Matheson and Morgan, 1958; Watson et al., 1958), and a direct comparison with this drug provides the most satisfactory method of assessing the value of a new compound of this type.<smiles>NS(=O)(=O)c1ccc(Cl)c(NC=Nc2ccccc2)c1</smiles>

CHLOROTHIAZIDE<smiles>Nc1ccc(O)c(NCCNc2ccccc2)c1</smiles>

HYDROCHLOROTHIAZIDE

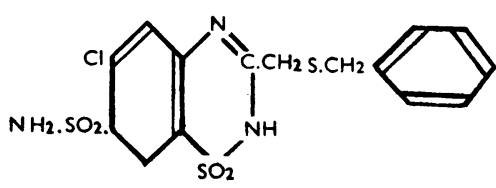

BENZTHIAZIDE

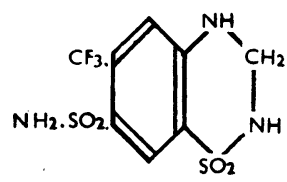

HYDROFLUMETHIAZID
FIG. 1.-Structural formulae of principal benzothiadiazine derivatives.

\section{Material and Methods}

The action of benzthiazide as compared with that of chlorothiazide was studied in two young men admitted to hospital for the investigation of minute tuberculous foci ; they had never been oedematous, and in all other respects their health was normal. The subjects continued moderate activity and no drugs other than those on trial were administered. Though dietary electrolytes were not accurately standardized, food and fluid intakes on the days of the experiments were quantitatively and qualitatively similar, and on this regime the two men had a similar pattern of electrolyte excretion. Urine was collected by evacuating the bladder at two-hourly intervals for 10 hours, and then a pooled collection was made of the urine passed in the next 14 hours. Observations were made both before and after the administration of single doses of $100 \mathrm{mg}$. of benzthiazide or $1 \mathrm{~g}$. of chlorothiazide, at least three days being allowed to elapse before another experiment with a diuretic was made. The two-hourly specimens were collected with strict anaerobic precautions, but mineral oil was not used, as it has been observed that $\mathrm{CO}_{2}$ is soluble in paraffin (Gambino, 1959). Without delay the $p \mathrm{H}, \mathrm{CO}_{2}$-content, and titratable acidity of these samples were determined; the volume and content of sodium, potassium, and chloride of all specimens were measured.

A clinical trial was conducted on 15 in-patients with oedema. The cause of the oedema was congestive cardiac failure in nine patients and hepatic cirrhosis in the remaining six. Fluid consumption was maintained at 1.5 litres daily and sodium intake was restricted to $25 \mathrm{mEq}$ a day $(1.5 \mathrm{~g}$. $\mathrm{NaCl}$ diet). With the exception of one patient (Case 10) no potassium supplements were given. All the patients were weighed daily and 24-hour collections of urine were made throughout. The trial was introduced by a four-day control period of bed rest, but this was curtailed in a few patients because of the severity of their condition; if treatment other than diuretics was being given prior to the trial this was kept constant throughout. After the control period one of the diuretics under trial was administered for four days ; an interval of two to four days without a diuretic was then allowed before administering the other drug for a further four days. The drug chosen to initiate therapy was alternated in successive patients. Daily dosage totalled $1 \mathrm{~g}$. of chlorothiazide or $100 \mathrm{mg}$. of benzthiazide. Urine volume and electrolyte excretion were measured daily, and the serum electrolytes and blood urea were estimated twice weekly. Screening tests for blood dyscrasia and hepatic dysfunction were also carried out.

Technical Methods.-Sodium and potassium were estimated by flame photometry ; chlorides by potentiometric titration, using a silver electrode; and carbon dioxide by a manometric method. Titrable acidity was determined by titration with $\mathrm{N} / 50 \mathrm{NaOH}$, using bromthymol blue indicator; urine $p \mathrm{H}$ by a glass electrode $p \mathrm{H}$ meter; and urine bicarbonate from the carbonic acid-bicarbonate curve according to $p \mathrm{H}$ (Peters and Van Slyke, 1932).

\section{Comparison of Action in Normal Subjects}

Urine changes in the two men were similar, and the results have therefore been presented as a mean (Table I, Fig. 2).

TABLE I.-Total 10-Hour Urinary Excretion After Benzthiazide and Chlorothiazide in Two Normal Men

\begin{tabular}{|c|c|c|c|c|}
\hline & & Control & $\begin{array}{c}\text { Benzthiazide } \\
\text { (100 mg.) }\end{array}$ & $\begin{array}{l}\text { Chlorothiazide } \\
\text { (1 8.) }\end{array}$ \\
\hline $\begin{array}{l}\text { Potassium (mEq) } \\
\text { Sodium ", } \\
\text { Chloride ", } \\
\text { Bicarbonate ,", } \\
\text { Titratable acid ," } \\
\text { Water (ml.) }\end{array}$ & $\begin{array}{l}\cdots \\
\cdots \\
\cdots \\
\cdots\end{array}$ & $\begin{array}{c}43 \\
51 \\
76 \\
7 \cdot 8 \\
8 \cdot 3 \\
1,170\end{array}$ & $\begin{array}{c}74 \\
139 \\
176 \\
7 \cdot 7 \\
9 \cdot 9 \\
1,840\end{array}$ & $\begin{array}{c}63 \\
144 \\
142 \\
36 \cdot 8 \\
4 \cdot 7 \\
2,080\end{array}$ \\
\hline
\end{tabular}

Urine Volume.-After both drugs the urine flow was maximal in the first six hours and had returned to little above control values within 10 hours, though peak water excretion was slightly delayed after benzthiazide as compared with chlorothiazide.

Electrolyte Excretion.-This ran parallel to water excretion after both drugs. Sodium excretion was similar, but benzthiazide caused a greater loss of chloride.

Changes in Acidity.-Titratable acid and $p \mathrm{H}$ were little altered by benzthiazide; chlorothiazide led to the secretion of an alkaline urine during the first six hours, 
but thereafter $p \mathrm{H}$ and titrable acidity were the same as on control days.

Bicarbonate Excretion.-This revealed the most characteristic difference, being greatly increased during the first six hours after chlorothiazide, whereas it was little altered by benzthiazide.

\section{Clinical Trial in Heart Failure}

Four patients (Cases 1, 4, 6, and 9-Table II) responded well to oral diuretics. Loss of weight is probably the best single index of progress, and these patients showed a mean weight loss of $5.5 \mathrm{~kg}$. $(12 \mathrm{lb}$.) during the combined periods of treatment with benzthiazide and chlorothiazide. The remaining five patients showed a fair or poor clinical response, with a mean loss of weight of $0.7 \mathrm{~kg}$. (1.5 lb.) during eight days' therapy; these patients had been subjected to dietary salt restriction for months or years and had received diuretics for long periods.

The two drugs produced similar effects in the same patients and appeared to be equally efficacious. In all cases benzthiazide caused a loss of chloride in excess of the urinary sodium loss, whereas excretion of these ions tended to be equimolecular after chlorothiazide. Potassium loss was of the same order in response to both drugs. Serum electrolytes did not manifest any

TABLE II.-Mean Effect of Benzthiazide $(100 \mathrm{mg} . /$ day) and Chlorothiazide $(1 \mathrm{~g} . /$ day) on Urinary Water and Electrolyte Excretion in Nine Patients with Congestive Cardiac Failure

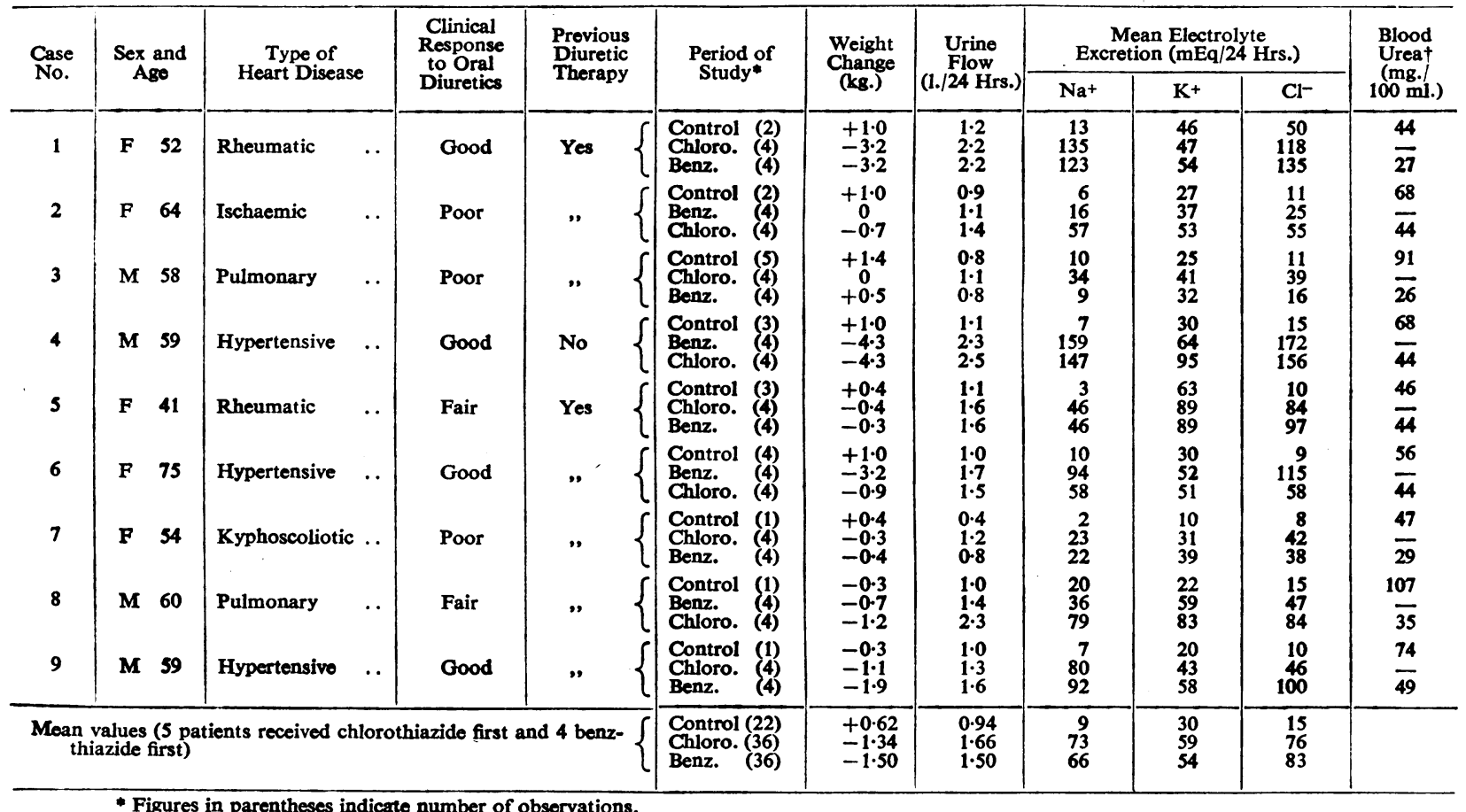

* Figures in parentheses indicate number of observations.
+ Values quoted are those before and after the complete trial (i.e., after the administration of both benzthiazide and chlorothiazide).

TABLE III.-Mean Effect of Benzthiazide (100 mg./day) and Chlorothiazide (1 g./day) on Urinary Water and Electrolyte Excretion in Six Patients with Hepatic Cirrhosis

\begin{tabular}{|c|c|c|c|c|c|c|c|c|c|c|c|c|c|}
\hline \multirow{2}{*}{$\begin{array}{l}\text { Case } \\
\text { No. }\end{array}$} & \multirow{2}{*}{\multicolumn{2}{|c|}{$\begin{array}{c}\text { Sex and } \\
\text { Age }\end{array}$}} & \multirow{2}{*}{\multicolumn{2}{|c|}{$\begin{array}{l}\text { Presenting } \\
\text { Complaint }\end{array}$}} & \multirow{2}{*}{$\begin{array}{c}\text { Serum } \\
\mathbf{A} / \mathbf{G} \\
\text { Ratio } \\
(\mathbf{g .} \%\end{array}$} & \multirow{2}{*}{$\begin{array}{l}\text { Previous } \\
\text { Diuretic } \\
\text { Therapy }\end{array}$} & \multirow{2}{*}{$\begin{array}{c}\text { Potassium } \\
\text { Supplements } \\
\text { (mEq' } \\
24 \mathrm{Hrs} \text {.) }\end{array}$} & \multirow{2}{*}{$\begin{array}{l}\text { Period of } \\
\text { Study* }\end{array}$} & \multirow{2}{*}{$\begin{array}{l}\text { Weight } \\
\text { Change } \\
\text { (kg.) }\end{array}$} & \multirow{2}{*}{$\begin{array}{c}\text { Urine } \\
\text { Flow } \\
\text { (1./ } \\
24 \text { Hrs.) }\end{array}$} & \multicolumn{3}{|c|}{$\begin{array}{c}\text { Mean Electrolyte } \\
\text { Excretion (mEq/24 Hrs.) }\end{array}$} \\
\hline & & & & & & & & & & & $\mathrm{Na}^{+}$ & $\mathbf{K}^{+}$ & $\mathrm{Cl}^{-}$ \\
\hline 10 & & 54 & Ascites & . & $3 \cdot 8 / 3 \cdot 1$ & Yes & 40\{ & $\begin{array}{ll}\text { Control (2) } \\
\text { Benz. (4) } \\
\text { Chloro. (4) }\end{array}$ & $\begin{array}{l}+0.5 \\
-0.5 \\
0\end{array}$ & $\begin{array}{l}1.0 \\
1.4 \\
1.6\end{array}$ & $\begin{array}{r}0 \\
12 \\
11\end{array}$ & $\begin{array}{r}41 \\
130 \\
126\end{array}$ & $\begin{array}{r}6 \\
80 \\
54\end{array}$ \\
\hline 11 & $\mathbf{F}$ & 39 & Oedema & .. & $1 \cdot 1 / 4 \cdot 2$ & ", & None & $\begin{array}{l}\text { Control (4) } \\
\text { Chloro. (4) } \\
\text { Benz. (4) }\end{array}$ & $\begin{array}{l}+1.0 \\
-1.8 \\
-1.8\end{array}$ & $\begin{array}{l}0.4 \\
0.4 \\
0.8\end{array}$ & $\begin{array}{r}4 \\
8 \\
13\end{array}$ & $\begin{array}{l}18 \\
17 \\
31\end{array}$ & $\begin{array}{r}4 \\
7 \\
13\end{array}$ \\
\hline 13 & $\mathbf{F}$ & 49 & Oedema & .. & $1.4 / 3.2$ & ", & " & $\begin{array}{l}\text { Control (2) } \\
\text { Chloro. (4) } \\
\text { Benz. (4) }\end{array}$ & $\begin{array}{l}-1.2 \\
-1.9 \\
-1.1\end{array}$ & $\begin{array}{l}1.5 \\
2.1 \\
1.9\end{array}$ & $\begin{array}{r}66 \\
104 \\
61\end{array}$ & $\begin{array}{l}40 \\
64 \\
71\end{array}$ & $\begin{array}{r}80 \\
139 \\
91\end{array}$ \\
\hline 14 & $\mathbf{F}$ & 67 & Ascites & .. & $2 \cdot 4 / 4 \cdot 1$ & " & ", & $\begin{array}{l}\text { Control (3) } \\
\text { Benz. (4) } \\
\text { Chloro. (4) }\end{array}$ & $\begin{array}{l}+1.3 \\
+1.4 \\
+0.9\end{array}$ & $\begin{array}{l}1 \cdot 3 \\
1 \cdot 1 \\
1 \cdot 2\end{array}$ & $\begin{array}{l}2 \\
3 \\
4\end{array}$ & $\begin{array}{l}38 \\
74 \\
51\end{array}$ & $\begin{array}{l}30 \\
80 \\
22\end{array}$ \\
\hline 15 & $\mathbf{F}$ & 52 & Ascites & .. & $2 \cdot 3 / 2 \cdot 4$ & No & ", & $\begin{array}{ll}\text { Control (1) } \\
\text { Chloro. (4) } \\
\text { Benz. (4) }\end{array}$ & $\begin{array}{l}+0.9 \\
-0.3 \\
-2.4\end{array}$ & $\begin{array}{l}0.5 \\
0.4 \\
0.7\end{array}$ & $\begin{array}{r}4 \\
6 \\
16\end{array}$ & $\begin{array}{l}13 \\
21 \\
48\end{array}$ & $\begin{array}{r}5 \\
11 \\
38\end{array}$ \\
\hline \multicolumn{8}{|c|}{ Mean values ( 3 patients received chlorothiazide first and 3 benzthiazide first) } & $\begin{array}{l}\text { Control (16) } \\
\text { Chloro. (24) } \\
\text { Benz. (24) }\end{array}$ & $\begin{array}{l}+0.48 \\
-0.65 \\
-1.10\end{array}$ & $\begin{array}{l}0.93 \\
1.13 \\
1.25\end{array}$ & $\begin{array}{l}13 \\
24 \\
24\end{array}$ & $\begin{array}{l}33 \\
55 \\
76\end{array}$ & $\begin{array}{r}26 \\
48 \\
7\end{array}$ \\
\hline
\end{tabular}


disturbance in response to either drug. Blood-urea levels before the trial ranged from 44 to $107 \mathrm{mg}$. $/ 100 \mathrm{ml}$.; in all patients these levels were reduced after the administration of both drugs. There was no evidence of hepatic or haematological disorder after either drug, nor was any gastro-intestinal disturbance observed.

\section{Clinical Trial in Hepatic Cirrhosis}

All the patients studied were advanced cases with low serum albumin levels (Table III), and three gave a history of neuropsychiatric complications. Two of these had undergone a portal-systemic shunt operation some years earlier and presented with oedema but no ascites. One of them (Case 13) was the only one in whom sodium excretion during the control period exceeded the dietary intake of this ion; she was also the only patient who responded well. Therapy was associated with an increased urinary loss of sodium and chloride with little change in potassium excretion, and serum potassium levels were unaltered. In the other patient (Case 11) treatment was associated with no appreciable increase in the excretion of sodium or potassium; the blood urea rose steadily, and she died a week later in hepatic coma.

The remaining four patients had ascites which had become refractory to conservative measures, and had been referred to this hospital (Mr. Alan Hunt) for consideration of portacaval anastomosis. Treatment with diuretics was associated with an increased urinary loss of potassium and chloride and no appreciable excretion of sodium. This potassium diuresis was accompanied in two patients by a mean loss of weight of $3.2 \mathrm{~kg}$. (7 lb.), but the other two failed to lose weight. In all these patients serum potassium levels fell to less than 3.5 $\mathrm{mEq} / 1$., and in two instances this was accompanied by drowsiness.

The quantitative response to the two drugs differed slightly (Table II-mean values); in the dosage used benzthiazide caused a greater increase in urinary volume and loss of weight. No toxic effects were observed with either drug.

\section{Discussion}

The patients included in this series provide a stringent test for any diuretic. A survey of Table II reveals that only one patient with congestive cardiac failure had not received previous diuretic therapy, and in all patients the daily excretion of sodium during the control period was less than the dietary intake $(25 \mathrm{mEq})$. This is largely due to the fact that since the advent of oral diuretics most patients with early congestive cardiac failure tend to be treated at home.

Our findings suggest that benzthiazide by mouth is an effective diuretic. When compared in normal and oedematous subjects a dose of $100 \mathrm{mg}$. produced a diuresis similar to that of $1 \mathrm{~g}$. of chlorothiazide. The differences between the two drugs are in the effective dosage and in their action on bicarbonate excretion. Chlorothiazide increases the excretion of bicarbonate, whereas benzthiazide does not.

The fact that chlorothiazide inhibits carbonic anhydrase was initially thought to explain the

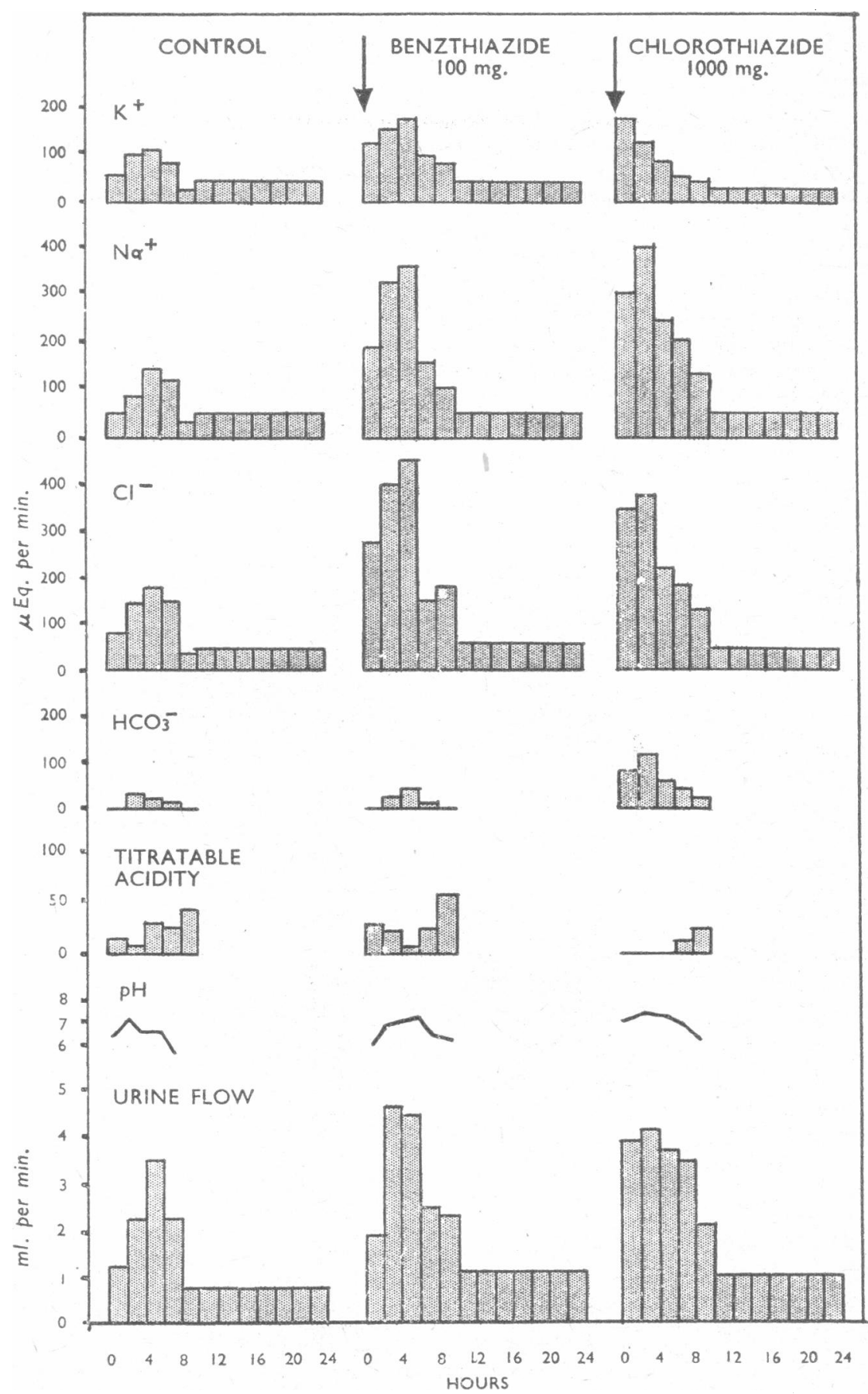

Fro. 2.-Mean effect of benzthiazide and chlorothiazide on urine volume and composition in two normal men. 
hypokalaemia with which administration of this drug may be associated (Slater and Nabarro, 1958). However, hydrochlorothiazide has little inhibitory activity on carbonic anhydrase (de Stevens et al., 1958) and yet its diuretic action and the tendency to cause potassium depletion are similar (Havard and Fenton, 1959 ; Platts, 1959). Hydroflumethiazide also causes less bicarbonate and more chloride excretion (Edmonds and Wilson, 1959), but the tendency to produce hypokalaemia is the same (Blagg, 1959).

We have found that benzthiazide causes a loss of chloride disproportionate to that of sodium. Bicarbonate excretion was unaltered, but potassium loss in the urine occurred just as readily. In our patients with congestive cardiac failure the mean potassium excretion after benzthiazide was $54 \mathrm{mEq} /$ day, compared with 59 $\mathrm{mEq} /$ day after chlorothiazide. Apart from this we encountered no toxic effects. The similar chemical structure of benzthiazide suggests that this drug may not be free from the occasional hazards of chlorothiazide (Nordqvist et al., 1959), though the smaller dosage may be advantageous.

\section{Summary}

Benzthiazide is a new oral diuretic chemically related to chlorothiazide. The action is similar to that of chlorothiazide, and a comparison of the two drugs suggests that $100 \mathrm{mg}$. of benzthiazide is approximately equivalent to $1 \mathrm{~g}$. of chlorothiazide. The action of the two drugs differed in two ways; after benzthiazide the urinary loss of chloride exceeded that of sodium, and bicarbonate excretion was not increased. In the treatment of oedema there was no less tendency to cause hypokalaemia.

We thank Dr. A. W. Spence for his constant help and encouragement; Dr. J. C. B. Fenton for much helpful advice; the consultant staff of St. Bartholomew's Hospital, who allowed us to study patients under their care; and Mrs. Eileen Akers for many of the electrolyte determinations. We also thank Miss K. Knapman and Miss $M$. Robinson and their nursing staff for their willing co-operation. Pfizer Ltd. suppied the benzthiazide (" fovane").

\section{REFERENCES}

Bayliss, R. I. S., Marrack, D., Pirkis, J., Rees, J. R., and Zilva, J. F. (1958). Lancet, 1, 120

Blagg, C. R. (1959). Ibid., 2, 311.

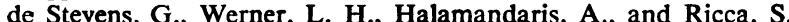
(1958). Experientia (Basel), 14, 463.

Edmonds, C. J., and Wilson, G. M. (1959). Lancet, 2, 303.

Gambino, S. R. (1959). Amer. J. clin. Path., 32, 270.

Havard, C. W. H., and Fenton, J. C. B. (1959). Brit. med. J., 1 1560 .

Matheson, N. A., and Morgan, T. N. (1958). Lancet, 1, 1195.

Nordqvist, P., Cramér, G., and Björntorp, P. (1959). Ibid., 1, 271.

Peters, J. P., and Van Slyke, D. D. (1932). Quantitative Clinical Chemistry, 2, 295. Baillière, Tindall and Cox, London.

Platts, M. M. (1959). Brit. med. J., 1, 1565.

Slater, J. D. H., and Nabarro, J. D. N. (1958). Lancet, 1, 124

Watson, W. C., Thomson, T. J., and Buchanan, J. M. (1958) Ibid., 1, 1199 .

In its Annual Report, 1959, the Central Council for the Care of Cripples refers to a controlled trial of the Spitz Holter valve in hydrocephalic children which it is financing - of necessity a long-term project-and to the problem of raising the standard of design and workmanship in goods made by the home-bound disabled. This is being further studied by the Council through its sponsorship of the newly formed Homecrafts Advisory Association.

\section{INOCULATION OF HUMAN VOLUNTEERS WITH STRAINS OF COE VIRUS ISOLATED IN BRITAIN}

BY

\author{
R. PARSONS, B.Sc.
}

M. L. BYNOE, M.B., D.T.M.\&H.

M. S. PEREIRA, M.B.

AND

D. A. J. TYRRELL, M.D., M.R.C.P.

The M.R.C. Common Cold Research Unit, Salisbury, Wilts ; and the Central Public Health Laboratory, Colindale, London

The Coe virus was first described by Lennette, Fox, Schmidt, and Culver (1958), working in California. They inoculated into HeLa cell cultures extracts of throat swabs from military personnel suffering from mild acute respiratory illnesses. The virus was isolated from four patients, its presence being recognized by degeneration of the cultures. Antibody rises were detected in five further patients with similar symptoms. Apparently identical viruses were isolated in Britain in 1958 from the throats of four R.A.F. recruits with illnesses described as febrile cold, febrile sore throat, or influenza (Pereira and Pereira, 1959). Many more isolations were made under similar circumstances in 1959. This report describes experiments carried out with the Coe virus obtained from the throats of two patients in the 1959 outbreak.

\section{Clinical and Laboratory Methods}

In these studies 35 volunteers aged 18-45 years were used ; they were housed, usually in pairs, at this unit, and were observed as described by Andrewes (1948) Specimens were collected as reported by Buckland, Bynoe, Philipson, and Tyrrell (1959).

Tissue Cultures.-Human amnion cultures were prepared as described by Zitcer, Fogh, and Dunnebacke (1955) and were maintained in medium 199. Human thyroid cultures were prepared (Pulvertaft, Davies, Weiss, and Wilkinson, 1959) in test-tubes in $20 \%$ calf serum and $0.5 \%$ lactalbumin hydrolysate in Hanks's saline, and were subsequently maintained in $2 \%$ calf serum and $0.25 \%$ lactalbumin hydrolysate in Hanks's saline. HeLa-cell cultures were prepared in test-tubes in $0.1 \%$ yeast extrast, $10 \%$ human serum, and $0.5 \%$ lactalbumin hydrolysate in Hanks's saline. The cultures were maintained in $5 \%$ rabbit serum and $0.25 \%$ lactalbumin hydrolysate in Hanks's saline. The human amnion and human thyroid cultures were maintained in a roller drum at $36^{\circ} \mathrm{C}$. The HeLa-cell cultures were maintained at $36^{\circ} \mathrm{C}$. in stationary racks.

The Viruses.-The prototype strain of Coe virus and hyperimmune monkey serum were provided by Dr. E. H. Lennette. These were used $(a)$ for neutralization tests with volunteers' sera, and (b) for typing viruses isolated from the throats and faeces of volunteers. The two throat swabs to be tested were immersed in Hanks's saline which was stored at $-60^{\circ} \mathrm{C}$. Immediately before use the fluids were diluted in Hanks's saline, and $1 \mathrm{ml}$. of this dilution was given to each volunteer as nasal drops. Coe virus was isolated from one of the throat swabs in human amnion cultures. A further passage 